\title{
The influence of the land drainage on the river runoff in Lielupe river basin district
}

\author{
Rasa Stankevičienė, Mindaugas Stankevičius \\ Department of Hydraulics Vilnius Gediminas technical university, Sauletekio ave. 11, LT-10223 Vilnius, Lithuania
}

\begin{abstract}
The evolution and influence of drainage of too wet lands in the Mūša, Lèvuo, Tatula and Nemunelis basins located in the Lielupe river basin district (RBD) on the river runoff in the period of 1960-2011 was analyzed. It was determined the wetland areas in the Mūša, Lèvuo and Nemunèlis basins exceed $70 \%$ and those of the Tatula basin - even $90 \%$ of the total basin area. Before 1961, the drainage areas covered only $4-7 \%$ of the territory of the basin and in 2000 these areas covered already $58-80 \%$. Lately, any new drainage systems almost are not developed, so the drainage areas have changed little.

Water surplus is most intensively removed during spring floods and summer high waters; therefore, due to draining influence the runoff in rivers varies only during the seasons of the same year.
\end{abstract}

Keywords: wet land; drainage; river runoff.

\begin{tabular}{|ll|}
\hline Nomenclature \\
$\Sigma Q_{p} \quad$ the sum of day and night debit during the period $t_{p}($ day $)$ \\
$Q_{p} \quad$ radius of $(\mathrm{m})$ debits are higher than the medium annual debit $Q\left(\mathrm{~m}^{3} / \mathrm{s}\right)$ \\
\hline
\end{tabular}

\section{Introduction}

More than half of the Lithuanian territory is the water surplus in soils. These areas cover $55.8 \%$ of the total area of the whole territory (3.4 mil. ha) or $85.9 \%$ of the total agricultural land use area. In the areas of water surplus intensive agriculture is possible only by having subsurface drainage. The scope of land drainage works had increased greatly since 1951. In the period of 1961-1990 particularly lots of reclamation works were carried out. In 1970 was 1 million, 1978 - 2 million, 1990-2.6 million ha of drained land. After the Restoration of Independence, when Lithuania had to shift from the planned to the market economy, the new drainage systems would not be erected. Besides, due to the lack of maintenance, some of the systems would stop functioning [1].

The influence of the reclamation to the natural environment is versatile [2], [3]. It changes not only the mode of water in the soil, but the agricultural landscape as well, the density of the hydro graphic network in the basins of rivers; the mode of the hydrologic territory (change of the runoff of rivers and its distribution during the year as well as the quality of the river waters); the conditions of works of the applied agricultural technology [4].

One of the first scientists who analyzed the influence of dewatering on the runoff of the Lithuanian rivers was V. Marčènas [5]. He stated that the activities concerned with drainage tend to reduce the runoff during separate seasons and later [6] when the investigation of the problem was carried out by means of simulation models he derived the conclusion that the activities of land reclamation and intensive farming insignificantly reduced the annual runoff. Other authors [7-9] stated that drainage had no significant effect on the maximum modulus of the runoff neither of the Year nor the Spring. It is proclaimed that when the area of drained lands in the river basins was increased up to $30 \%$, the modulus of the runoffs of Summer and Autumn maximum high waters tends to increase by $30-40 \%$, where the coefficients of the runoffs were $30 \%$, and the duration of high waters was reduced by $7 \%$. Research carried out by other authors [10] indicated that by increasing the per cent of land under drainage in the basin registered a reduction of the coefficients of the runoffs during Spring floods, but the coefficients of the runoffs of Summer and Autumn periods and through the whole year tend to be increased.

Corresponding author: Rasa Stankevičienė. E-mail address: rasa.ruminaite@vgtu.lt

http://dx.doi.org/10.3846/enviro.2014.095

(C) 2014 The Authors. Published by VGTU Press. This is an open-access article distributed under the terms of the Creative Commons Attribution License, which permits unrestricted use, distribution, and reproduction in any medium, provided the original author and source are credited. 
In other countries, there are not many studies dealing with the drainage impact of river runoff. Belarus and Russia, mainly to carry out studies of river basins dominated marsh soils. Belarus and Russia, most research is done in river basins where soils are dominated by marsh [11], [12]. Some authors argue that drained wetlands, annual river runoff increases, others argue the contrary, that it is reduced. After the installation of drainage systems, changing the structure of agricultural land. They change alters the hydrological regime of the rivers [13-16]. It is important to analyze rivers runoff changes, because it has a direct impact on water quality and pollution.

The aim of our work is to evaluate the influence of the drainage of periodically excessively wet lands upon the alternation of annual river runoff and the hydrologic characteristics of spring and summer runoff in Lielupe river basin district (RBD).

\section{Research subject and methodology}

The researches involved the second largest Lielupe river basin district (RBD) situated in the northern part of Lithuania, belonging to karst region and covering $13.8 \%$ of the territory of the Lithuanian Republic, see Fig. 1.

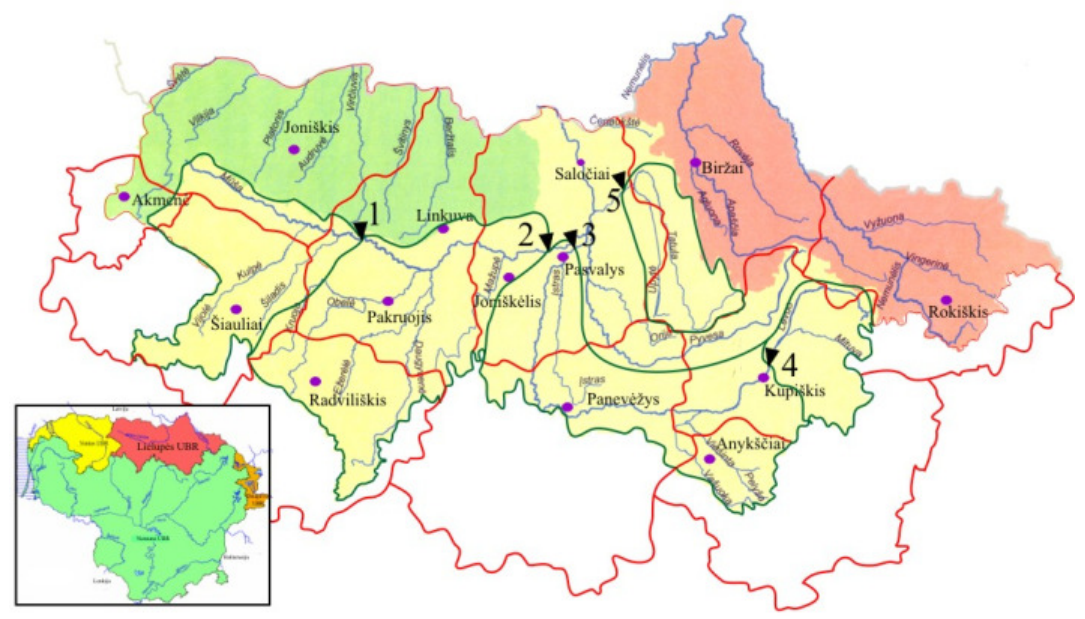

Fig. 1. Lielupe river basin district, the boundaries of its administrative regions and the rivers with their water measurement stations: $1-$ Mūša - Miciūnai; 2 - Mūša - Ustukiai; 3 - Lèvuo - Pasvalys; 4 - Lèvuo - Kupiškis; 5 - Tatula - Trečionys

The alternation of drained lands. The alternation of drained land areas ( $\%$ of basin territory and of wet land fond) in the great Muša, Lèvuo, Tatula and Nemunèlis river basins of Lielupe river basin district to the water measurement stations was estimated using the wet land cadaster prepared by A. Sakalauskas and L. Zelionka [17].

In order to analyze the alternation of the drained lands the data of the statistical accounting of drained lands were used [18]. The rivers under examination are situated in the territory of several administrative districts, so the abovementioned data were collected within the bounds of municipalities' territories. Later the data were recast for the river basin district, finding out which part of each river basin territory is covered by wet and drained land areas.

The establishment of river wateriness and river runoff alternation. In order to analyze the alternation of rivers wateriness the data of long-term water discharge measurements (the period of 1960-2011) gathered in Lithuanian Hydrometeorological Service were used. Hydrological observations of Muša river were performed at water measurement stations of Miciūnai and Ustukiai, Lèvuo - Pasvalys and Kupiškis, Tatula - Trečionys, Nemunèlis - Tabokinè. Hydrological observations of the rivers were performed every day. The characteristics of the river basins chosen for the analysis are given in the Table 1.

Table 1. The investigated rivers basin characteristic

\begin{tabular}{|c|c|c|c|c|c|c|}
\hline \multirow[b]{2}{*}{ The characteristics of the river basins } & \multicolumn{6}{|c|}{ Rivers and water measurement stations } \\
\hline & 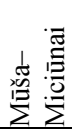 & 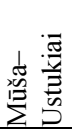 & 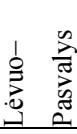 & 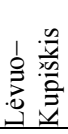 & 点 & 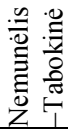 \\
\hline Basin area $\mathrm{km}^{2}$ & 792 & 2280 & 1560 & 307 & 404 & 2690 \\
\hline Wet lands fund, $\%$ of catchment area & 71 & 76 & 72 & 70 & 89 & 73 \\
\hline Lakes area, $\%$ & 2.1 & 0.8 & 0.4 & 0.4 & - & 0.6 \\
\hline Wet land area, $\%$ & 5.0 & 3.0 & 8.0 & 5.0 & 8.0 & 10.0 \\
\hline Forest area, $\%$ & 17.0 & 14.0 & 15.0 & 12.0 & 8.0 & 24 \\
\hline
\end{tabular}

On the ground of water discharge measurement data the height of annual, spring and winter run off was analyzed. 
The increasing number of drained land areas in river basins can change the duration of floods and high water, affect the size of discharge modules. With an eye to assess possible changes we ascertained the trends of the alternation of maximal discharge modules of spring floods and summer high water and their dependence on the increasing areas of drained lands within the period of 1960-2011. Spring season included March and April. Summer season included 4 months: May, June, July and August.

In order to assess the runoff distribution during the year in the period of various wateriness (less watery in 1960 1969 and more watery in 1981-1990) we analyzed the alternation of runoff inequality coefficients $d$. In the period of 19601969 there were $7-40 \%$ of drained lands (\% of the territory of the basins under examination), the annual amount of precipitations according to the data of Biržai and Panevėžys meteorological stations was close to norm (605 and $593 \mathrm{~mm})$. In 1981-1990 when the areas of drained lands in the basins under examination amounted to 52-80\%, the annual amount of precipitations exceeded the norm more than by $10 \%$.

The runoff inequality coefficients d calculated by the following formula (1):

$$
d=\frac{\sum Q_{p}-Q t p}{365(6) \cdot Q}
$$

With an eye to analyze runoff changes we used the parameters of main runoff characteristics (discharges, runoff modules, runoff height) and statistical parameters (averages, amplitudes and modular coefficients).

\section{Results of research}

Planning the conservation means and the development of economic activity in karst region it was important to assess that owing to anthropogenic activity, water circulation changes between surface and groundwater aquifers are possible. For this reason we analyzed the territories of Muša, Lèvuo, Tatula and Nemunèlis river basins situated in Lielupe river basin district, the development of excessively wet lands drainage and the influence on river runoff within the period of 1960-2011. In the basins of these rivers excessively wet lands amount $70-89 \%$ of basins area. All river basins under examination include the areas of small lakes (hardly $0.4-2.1 \%$ ) and marshes (3.0-10.0\%), only small part of which (about $3 \%$ of their total area) is drained; in these basins periodically wet mineral soils are drained the most.

The alternation of drained land areas. The drainage of Lielupe RBD lands is an important tool which allows establishing favorable conditions for intensive agriculture. However, in drained lands surface runoff decreases and underground runoff increases. Such changes can have an effect on the trends of river runoff distribution per year and runoff value in particular seasons.

Wet land areas in Muša, Lèvuo and Nemunèlis river basins amount to more than $70 \%$, whereas in Tatula river basin - even about $90 \%$ of total area. After the analysis of the alternation of excessively wet land and drained land areas within 1960-2011 in the basins of the rivers under examination (Table 2) it was found out that until 1961 drained land areas amounted only to $4-7 \%$ of basin territory or $7-12 \%$ of wet land area. In 1970 drained land areas in basins under examination amounted to $32-47 \%$ of basin territory or $44-53 \%$ of wet land area. In 1980 (in comparison with situation until 1970) the number of drained lands noticeably increased and reached from 71 to $80 \%$ of wet land area. In another ten years, in 1990 drained lands in the basins under examination amounted to $58-81 \%$ of basin territory, or $78-88 \%$ of wet land fond. In 2000 in Muša, Lèvuo and Nemunèlis river basins the areas of drained lands amounted to 80-89\%, whereas in Tatula river basin (to Trečionys water measurement station) $-91 \%$ of wet land fond. In these latter years new drainage systems aren't almost prepared, thus the number of drained lands has slightly changed.

Table 2. Variation of drained land areas in the investigated river basins: a - drained land area in percent of total basin area; $\mathrm{b}$ - in percent of wetland area)

\begin{tabular}{|c|c|c|c|c|c|c|c|c|c|c|c|c|}
\hline \multirow{3}{*}{ Years } & \multicolumn{12}{|c|}{ Rivers and water measurement stations } \\
\hline & \multicolumn{2}{|c|}{$\begin{array}{l}\text { Mūša- } \\
\text { Miciūnai }\end{array}$} & \multicolumn{2}{|c|}{$\begin{array}{l}\text { Mūša- } \\
\text { Ustukiai }\end{array}$} & \multicolumn{2}{|c|}{$\begin{array}{l}\text { Lèvuo- } \\
\text { Pasvalys }\end{array}$} & \multicolumn{2}{|c|}{$\begin{array}{l}\text { Lèvuo- } \\
\text { Kupiškis }\end{array}$} & \multicolumn{2}{|c|}{$\begin{array}{l}\text { Tatula- } \\
\text { Trečionys }\end{array}$} & \multicolumn{2}{|c|}{$\begin{array}{c}\text { Nemunèlis- } \\
\text { Tabokiné }\end{array}$} \\
\hline & $a$ & $b$ & $a$ & $b$ & $a$ & $b$ & $a$ & $b$ & $a$ & $b$ & $a$ & $b$ \\
\hline 1961 & 6 & 8 & 7 & 7 & 7 & 9 & 7 & 12 & 4 & 7 & 5 & 8 \\
\hline 1970 & 32 & 44 & 37 & 48 & 36 & 49 & 35 & 47 & 47 & 53 & 34 & 48 \\
\hline 1975 & 43 & 53 & 48 & 61 & 43 & 59 & 47 & 54 & 60 & 67 & 47 & 62 \\
\hline 1980 & 54 & 75 & 58 & 75 & 52 & 71 & 59 & 72 & 72 & 80 & 56 & 73 \\
\hline 1985 & 58 & 78 & 63 & 81 & 57 & 76 & 62 & 75 & 78 & 84 & 59 & 78 \\
\hline 1990 & 60 & 83 & 66 & 86 & 58 & 80 & 64 & 78 & 81 & 88 & 62 & 81 \\
\hline 1995 & 58 & 82 & 69 & 87 & 60 & 81 & 67 & 79 & 81 & 89 & 79 & 82 \\
\hline 2000 & 58 & 81 & 68 & 89 & 59 & 82 & 63 & 80 & 80 & 91 & 80 & 83 \\
\hline 2011 & 58 & 81 & 68 & 89 & 59 & 82 & 63 & 80 & 80 & 91 & 80 & 83 \\
\hline
\end{tabular}


River runoff alternation. In order to evaluate the runoff distribution per year we performed the calculations of runoff inequality coefficients $d$ values within two different periods. It was found out that within the period of 1960-1969, when the part of drained lands was small, the values of runoff inequality coefficient changed from 0.51 (in Tatula and Lèvuo rivers) to 0.59 in Muša river. Within the period of 1981-1990, when the area of drained lands was about twice as large, runoff inequality coefficients changed from 0.43 to 0.52 - relatively decreased by $11-15 \%$. Compared these changes with the values established within longstanding period [19], which changed from 0.46 to 0.56 , it can be seen that there were no substantial changes. Such values of runoff inequality coefficients mean that, firstly, these rivers have the least even runoff per year, and, secondly, that drainage does not have substantial influence on the changes of investigated rivers runoff distribution per year.

Seasonal runoff changes in drained areas within the longstanding period. After the analysis of hydrological data we made the hydrographs of spring and summer maximal discharge modules in which derived direction lines did not show considerable change trends. Calculated correlation coefficients within the period under consideration are very small, they changed from 0.25 to 0.36 in spring months and from 0.06 to 0.12 in summer months. These results allow stating that in case of the increase of drained areas in river basins there is no clear alternation trend of both spring floods and summer high water maximal discharge modules. Only the hydrographs of spring flood maximal discharge modules make it possible to notice that in case of the increase of drained areas in the basin very trifling maximal discharge modules decrease trends are observed. Most probably that the maximal values of discharge modules, which were observed given very different drained land areas, are determined by the conditions of global climate change - warmer winters and thereby earlier snow melting.

Large spring maximal discharge modules $-127-190 \mathrm{l} /\left(\mathrm{s} \cdot \mathrm{km}^{2}\right)$ - were observed at the beginning of the period under consideration (in 1962, 1967, 1970), when drained land areas in river basins did not reach even $40 \%$ of total basin area. Besides, large discharge modules were found at the end of the period under consideration $(1996,1999)$, when the larger half of wet lands had already been drained. During summer high water maximal discharge modules were significantly smaller in comparison with spring flood discharge modules. The highest values were recorded in summers of 1983-1987 when they reached $38-58 \mathrm{l} /\left(\mathrm{s} \cdot \mathrm{km}^{2}\right)$.

The highest values of runoff height were observed within the years when the amount of precipitations was higher than norm. During spring season runoff height in rivers under examination changed from 9 to $195 \mathrm{~mm}$, whereas in summer season - from 6 to $129 \mathrm{~mm}$. The highest change amplitudes of spring and summer runoff height during the whole period under consideration were observed in Tatula river. There were years when in this river spring runoff height reached 195, and summer $-129 \mathrm{~mm}$. Higher fluctuations of runoff height in this river can be determined by small basin area, because small river basins are very sensitive to the impact of natural factors. The smallest change amplitude was observed in Lèvuo river beside Pasvalys, where spring runoff height did not exceed 100, and summer $-48 \mathrm{~mm}$. The similar alternation of runoff height amplitudes was observed in Lèvuo river beside Kupiškis.

The highest frequent runoff height values were established within 1986-1990, when the amount of precipitations was by $13 \%$ higher than precipitation norm. The smallest runoff height values were established within 1971-1975, when the amount of precipitation was by $11 \%$ smaller than precipitation norm (Fig. 2).

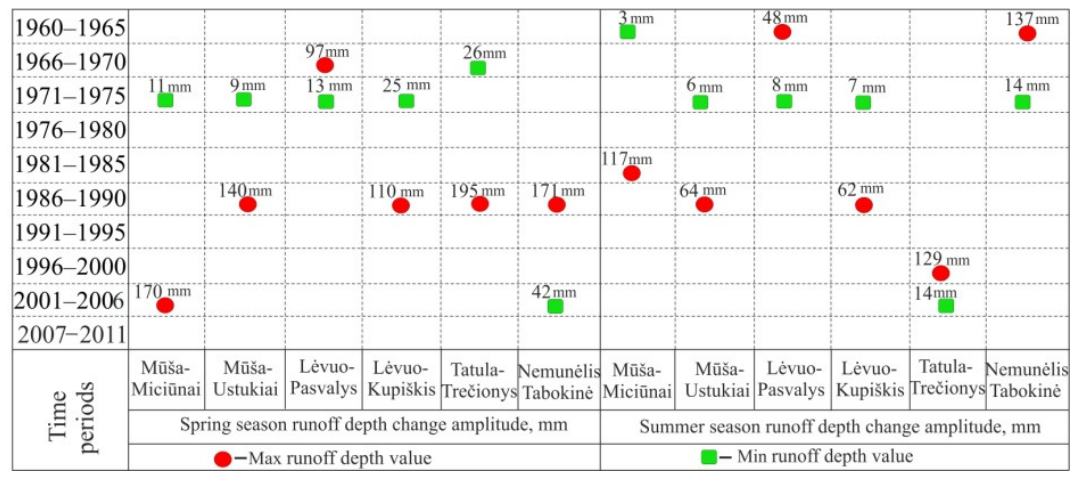

Fig. 2. Amplitudes of runoff depth

Analyzing the alternation of spring and summer runoff heights and drained land areas equal regularities were found out (Table 3 and Figs 3, 4).

During spring season the correlation dependence of runoff height on drained land area (considering both according to the part of wet land area in the whole river basin and according to the part of drained lands of wet land fond) in all rivers under examination is very weak or there is no any correlation - correlation coefficients change from -0.17 to 0.22 .

The same regularity is established in the alternation of summer runoff height. Correlation dependence between summer runoff height and drained lands area changes from -0.04 to 0.44 .

It is possible to evaluate more objectively the influence of drainage on river runoff analyzing what part of water flowing down the river during spring floods and summer high water amounts of annual runoff. After the analysis of the dependence of these values alternation upon the drained land area, it was discovered that the increase of drained land areas both during 
spring and summer seasons did not have any influence (Table 4) - there is no any correlation between these values or only weak positive or negative correlation is found (the alternation of correlation coefficients is from -0.52 to 0.19 ).

Table 3. Correlation coefficients $r$ between the runoff depth in $\mathrm{mm}$ and area of drained land

\begin{tabular}{lcc}
\hline & \multicolumn{2}{c}{ Correlation coefficients } \\
\cline { 2 - 3 } The rivers and water & Relationship between the spring runoff depth (in mm) and drained area (in percent) \\
\cline { 2 - 3 } measurement stations & $0.18^{* * *}$ & from wetland fund in the basin area \\
\hline Mūša - Miciūnai & $-0.11 * * *$ & $0.22^{* * *}$ \\
Mūša - Ustukiai & $-0.17^{* * *}$ & -0.02 \\
Lèvuo - Pasvalys & $0.19 * *$ & $-0.16^{* * *}$ \\
Lèvuo - Kupiškis & 0.01 & $0.21 * *$ \\
Tatula - Trečionys & $0.12^{* * * *}$ & -0.02 \\
Nemunèlis-Tabokine & & $0.14 * * *$
\end{tabular}

\begin{tabular}{lcc}
\hline \multicolumn{2}{c}{ Relationship between the summer runoff depth (in mm) and drained area (in percent) } \\
\hline Mūša - Miciūnai & $0.44^{*}$ & $0.44^{*}$ \\
Mūša - Ustukiai & $0.21^{* *}$ & $0.24^{* *}$ \\
Lèvuo - Pasvalys & -0.03 & -0.04 \\
Lèvuo - Kupiškis & $0.37^{*}$ & $0.39^{*}$ \\
Tatula - Trečionys & 0.26 & 0.26 \\
Nemunèlis-Tabokine & $0.31^{* * *}$ & $0.34^{* * *}$ \\
\hline
\end{tabular}

$* *-$ reliability at the $95 \%$ probability level of $\mathrm{p}<0.05$
$* *-$ reliability at the $90 \%$ probability level of $\mathrm{p}<0.1$
$* * *-$ reliability at the $80 \%$ probability level of $\mathrm{p}<0.2$

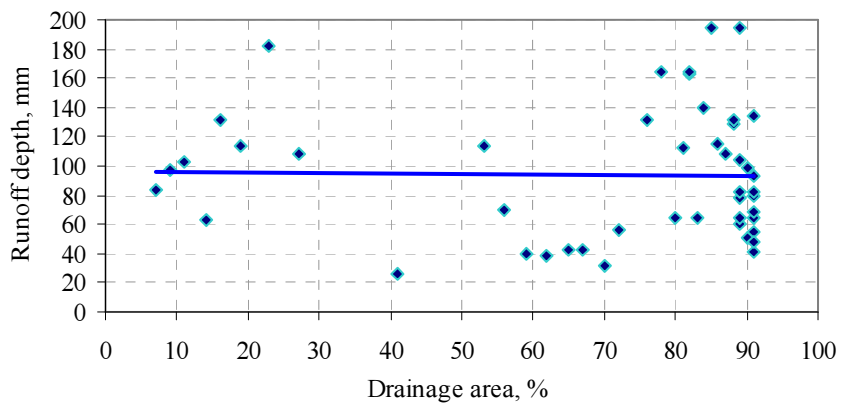

Fig. 3. Relationship between the spring runoff depth of the Tatula river and drained area in the river basin (in percent of wetland area)

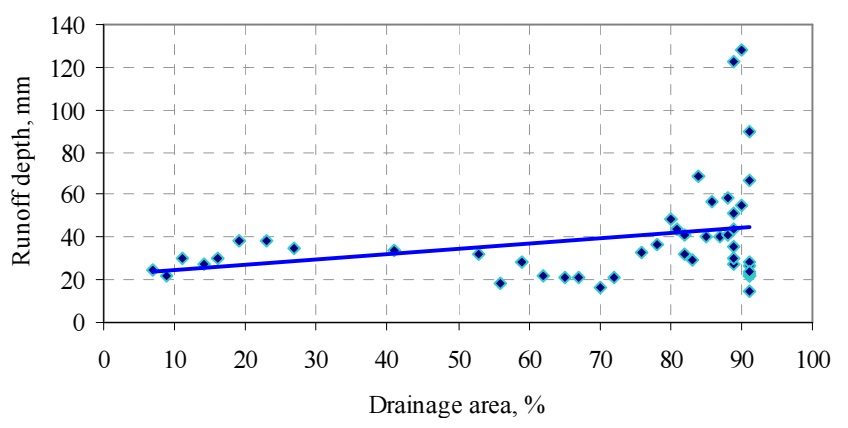

Fig. 4. Relationship between the summer runoff depth of the Tatula river and drained area in the river basin (in percent of wetland area)

Table 4. Data characterizing relation between the runoff depth and drained land area (in percent of wetland area)

\begin{tabular}{lcc}
\hline $\begin{array}{l}\text { The rivers and water } \\
\text { measurement stations }\end{array}$ & Regression equations & Correlation coefficients \\
\hline \multicolumn{1}{c}{ Spring runoff depth from the annual runoff depth } \\
\hline Mūša-Miciūnai & $R=-0.33 b+58.57$ & $-0.52^{*}$ \\
Mūša-Ustukiai & $R=-0.25 b+59.198$ & $-0.38^{*}$ \\
Lèvuo-Pasvalys & $R=-0.24 b+58.08$ & $-0.35^{*}$ \\
Lèvuo-Kupiškis & $R=0.02 b+29.21$ & $0.03^{* * *}$ \\
Tatula-Trečionys & $R=-0.20 b+57.45$ & $-0.36^{*}$ \\
Nemunèlis-Tabokine & $R=0.03 b+31.22$ & $0.21^{*}$ \\
\hline
\end{tabular}




\begin{tabular}{lcc}
\hline \multicolumn{3}{c}{ Summer runoff depth from the annual runoff depth } \\
\hline Mūša-Miciūnai & $R=0.04 b+11.88$ & $0.17^{* *}$ \\
Mūša-Ustukiai & $R=0.01 b+13.60$ & $0.02 * * *$ \\
Lèvuo-Pasvalys & $R=-0.03 b+20.22$ & $-0.14^{* *}$ \\
Lèvuo-Kupiškis & $R=0.06 b+10.01$ & $0.19^{* *}$ \\
Tatula-Trečionys & $R=0.02 b+16.72$ & $0.06^{* * *}$ \\
Nemunèlis-Tabokine & $R=0.04 b+9.21$ & $0.18^{* *}$ \\
$* \quad-$ reliability at the $95 \%$ probability level of $\mathrm{p}<0.05$ & \\
$* * \quad$ - reliability at the $80 \%$ probability level of $\mathrm{p}<0.2$ & \\
$* * *$ - reliability at the $60 \%$ probability level of $\mathrm{p}<0.4$ &
\end{tabular}

The conducted researches show that the change of drained land areas did not have influence on the alternation of runoff height (both during the periods of spring floods and summer high water).

\section{Conclusions}

Wet land areas in Muša, Lėvuo and Nemunèlis river basins amount to more than $70 \%$, whereas in Tatula river basin - even about $90 \%$ of total area. It was established that until 1961 drained land areas amounted hardly to 4-7\% of basin territory, whereas in 2011 these areas reached $58-80 \%$. In these latter years new drainage systems are not almost prepared, thus the areas of drained lands have slightly changed.

In case of the increase of drained land area in the river basins under examination there is no clear trend of both spring flood and summer high water maximal discharge module alternation. The calculated correlation dependence is very weak: from 0.25 to 0.35 in spring months and from 0.05 to 0.11 in summer months.

After the analysis of runoff alternation dependence upon drained land area it was established that both during sprint floods and summer high water periods the increase of drained land areas in river basins under examination does not have impact on river runoff alternation. Correlation dependence between spring and summer runoff height and drained land area is very weak or weak. During spring season correlation coefficients change from -0.17 to 0.22 , during summer season from -0.04 to 0.44 . In case of the increase of drained land areas in Muša, Lèvuo, Tatula and Nemunèlis river basins there are no any substantial annul changes of runoff alternation found. Data analysis shows that there are cyclical fluctuations typical of runoff alternation, when the phases of watery circle replace dry phases. Besides, there is seasonality typical of runoff alternation.

\section{References}

[1] Ruminaitè, R. 2010. Antropogeninès veiklos įtakos upių nuotékiui ir vandens kokybei tyrimai ir vertinimas upių nuotèkiui ir vandens kokybei tyrimai ir vertinimas [Research and evaluation on the anthropogenic activity impact on the river runoff and water quality]. Vilnius: Technika. $180 \mathrm{p}$.

[2] Lukianas, A. 2006. Melioracijos hidrotechniniu statiniu poveikio gamtinei aplinkai tyrimai ir vertinimas [Reclamation works of hydraulic impact on the natural environment, research and evaluation]. Vilnius: Technika. $31 \mathrm{p}$.

[3] Balzarevičius, P.; Lukianas, A.; et al. 1983. The Complex Cultivation of the Soils. Moscow: Kolos 208 p.

[4] Balčiūnas, A.; Lukianas, A.; et al. 1975. Experience of Land Cultivation by Drainage in Lithuania. Moscow: Kolos, 1975, 13-17, 70-98.

[5] Marčènas, V. 1970. Some Issues on the Influence of Drainage on the Runoff Volume, in the jubilee conference in the Republic of Lithuania on meteorology 2: 56-57.

[6] Marčènas, V. 1991. Sausinimo ir intensyvios žemdirbystės poveikis upių nuotėkiui [Drainage and intensive farming impact of river runoff], Regioninė hidrometeorologija 14: 33-45.

[7] Lukianienè, D. 1970. The influence of drainage on to the maximum spring runoff in the rivers of Lithuanian SSR, Articles on Hydrometeorology 5(3): 47-53.

[8] Lukianienè, D. 1973. Pavasario nuotekis drenuotuose ir nedrenuotuose baseinuose [The spring runoff in the drained and non-drained basins], Articles on Hydrometeorology 6: 15-19.

[9] Macevičius, J.; Lukianienè, D. 1975. Mineralinių žemių nusausinimo poveikis Lietuvos TSR upių vidutiniam metiniam nuotèkiui [Mineral soil drainage impact on the average annual river runoff in the Lithuanian SSR], Hidrometeorologiniai straipsniai 7: 33-45.

[10] Juozapaitis, A.; Zelionkiené, V. 1997. Practical issues concerning determination of the anthropogenic influence on changes of elements of river basin water balance and measures for their solutions, Lietuvos žemès ūkio universiteto ir Lietuvos vandens ūkio instituto mokslo darbai 3(25): 78-81.

[11] Водогредский, И. Е. 1990. Антропогенное изменение стока малых рек [Маžų upių nuotèkio antropogeninis pokytis]. Ленинград. 176 с.

[12] Балзарявичюс, П.; Лукянас, А. и др. 1983. Комплексное окультуривание земель [Kompleksinis žemių sukultūrinimas]. Mocква: Колос. 208 с.

[13] Pauliukevičius, H. 2000. Žemès naudmenų transformacijų poveikis azoto ir fosforo koncentracijoms upių vandenyje[Impact of land use transformation of nitrogen and phosphorous concentrations in river water], Vandens ūkio inžinerija 13(35): 24-29.

[14] Ren, L.; Wang, M.; Li, C.; Wei, Z. 2002. Impacts of human activity on river runoff in the northern are, Journal of Hydrology $261: 204-217$. http://dx.doi.org/10.1016/S0022-1694(02)00008-2

[15] Ashagrie, A. G.; Latt, P. J.; Witt, M. J.; Tu, M.; Uhlenbrook, S. 2002. Detecting the influence of land use changes on floods in the Meuse river basin the predictive power of a ninety-year rainfall-runoff relation, Hydrology and Earth System Science 3: 529-559. http://dx.doi.org/10.5194/hessd-3529-2006

[16] Oginski, B. 2007. Hydrological response to land use changes in Central European lowland forest catchments, Journal of Environmental Engineering and Landscape Mangement 15(1): 3-13.

[17] Sakalauskas, A.; Zelionka L. 1980. Lietuvos TSR šlapiu žemiu kadastras [Lithuanian SSR wetland cadastre]. Vilnius: Vaga. 831 p.

[18] Valstybinis žemetvarkos institutas. 2007. Melioruota žemė ir melioracijos statiniai [Reclaimed land and reclamation installations]. Vilnius. 47 p.

[19] Gailiušis, B.; Jablonskis, J.; Kovalenkovienè, M. 2001. Lietuvos upès. Hidrografija ir nuotèkis [Lithuanian rivers. Hydrograph and runoff]. Kaunas, 794 p. ISBN-9986-492-64-5. 